\section{ENZYME TECHNOLOGY}

\section{Towards Biochemical Engineering}

Because the biologica] sciences have never been regarded as capital intensive, the grant of $£ 200,000$ which has just been awarded for biochemical engineering at University College London seems large. In relation to the cost of the equipment being used, and the possibilities which may be opened up by this relatively new branch of science, however, the size of the grant is not surprising. Indeed, it is one of the first grants to be made by the newly established Enzyme Chemistry and Technology Committce of the Science Research Council, and shows the council's desire to stimulate and consolidate work in the field of enzyme technology.

At University College, the announcement has naturally been greeted with enthusiasm, for it will allow it greatly to expand research into techniques for controlling the levels of particular enzymes in microorganisms, for large-scale isolation of these enzymes and for stabilizing them by attachment to solid supports. The biological engineering team is an interdisciplinary group, consisting of biochemists and chemical engineers. It was set up in 1959, and now runs a formal course in biochemical engineering, accepting graduates from biochemistry and chemical engineering to study for MSc degrees. The research team, which numbers about twenty, feels that the fact that its members are drawn from two disciplines is particularly valuable for gaining a new approach to problems in biochemistry.

The area of research which will probably benefit most from this injection of capital is the development of techniques for large-scale isolation of enzymes from plants and microorganisms. Two methods are being followed-continuous isolation and simultaneous isolation of several different intracellular enzymes from one cell. The team has already operated a pilot plant for the continuous extraction of several enzymes, processing an input of the order of $20 \mathrm{~kg}$ an hour of plant material. This process requires very sophisticated equipment for recovering by centrifugation solid particles and by controlling the $p \mathrm{H}$ of the various stages of the process; one of the most pressing requirements is a 1,000 litre fermentation unit. X-ray diffraction and nuclear magnetic resonance analyses of enzymes require relatively large quantities of material, and this is one reason for intensifying research on enzyme extraction, but the main incentive lies in the possibility of using enzymes to catalyse a variety of industrial processes.

The industrial application of enzyme technology is undoubtedly the chief reason why the SRC has given the subject such a high priority, and the interest now being shown in this field, particularly in America and Japan, indicates that the potential of enzyme catalysis is very good. Before enzymes can be used in a continuous process, however, they must be stabilized, because they are particularly delicate molecules. A promising method for doing this is to attach them to a solid support, such as cellulose or glass, and research in this direction will form the second largest part of the UCL research programme. If these techniques can be perfected at UCL, the next step will be to persuade industry to adopt enzyme catalysis in processes which use other methods at the moment, or to change from processes in which enzymes are added in batches, to continuous processes. If this can be done, it could lead to great changes, for example, in producing sugar from starch and in the manufacture of penicillin.

\section{GERMAN SCIENCE \\ Brandif's New Broom}

THe surprising appointment of Professor Hans Leussink to the post held with such éclat by Dr Gerhard Stoltenberg (CDU) in the previous West German government, together with a change of title, suggests that the new minister will have a different role from that of his predecessor and that university reform may be a major aim of the new German administration.

This ministry was previously called Wissenschaftsforschung-scientific research. It is renamed the Ministry of Bildungs und Wissenschaft-education and science. In his brief first public statement on policy last week, the new Chancellor declared that first consideration was to be given equally to two areas of national life: "the stability and growth of economic production" and "questions concerning education and research policy".

Professor Leussink is not a politician and is not known to belong to any political party. He has made his name as chairman of the Wissenschaftsrat, the body that advises the government on scientific matters. Two years ago, he published on behalf of this body a paper on university reform that caused a considerable stir; its main recommendation was an intermediate exam. ination for students. The German university system is almost as mediaeval as when Hamlet and Horatio attended Wittenberg. There is no examination betwcen the abitur ("going away" exam), taken at school, and the degree examination. Courses are open to anyone who has gained an abitur and there is no time limit for the completion of a degree. Students may attend any university or move from one to another. This imposes a heavy strain on the universities and is increasingly considered to be a wildly extravagant use of the country's resources. An intermediate exam would at least provide some selectiveness.

The German universities are at present the responsibility of the Länder. Federal government influence is limited to the supply of funds through the Max Planck Society and direct from the Research Ministry for particular research or for the setting up of new courses.

The man most widely tipped for Dr Stoltenberg's job before the Cabinet appointments were announced was Dr Klaus von Dohnanyi (SPD), parliamentary secretary at the Economic Ministry under Dr Schiller. He is now parliamentary secretary in Professor Leussink's ministry. It seems likely that Dr Dohnanyi may be left to guide research policy as it affects industry and the economy, while Professor Leussink concerns himself with problems related more specifically to education.

Dr Stoltenberg laid a good foundation in promoting long-term advanced research in fields calculated to stimulate German industry, and notably in the nuclear, aerospace and computcr fields. Is this achievement to be thrown away? Dr Schiller, the Economics Minister, has recently been speaking in favour of support of short-term, commercially predictable projects. It is assumed that these efforts will be grafted on to the existing research structure, not that Stoltenberg's concept of areas of excellence will be discarded. 